\title{
METHODOLOGY OF TESTING FOIL BEARINGS IN THE START-STOP CYCLE IN THE PRESENCE OF A WORKING MEDIUM - STABILIZATION OF TEMPERATURE IN THE TEST CHAMBER
}

\author{
Bartosz Moczulak $^{\mathrm{a}}$, Wojciech Miąskowski ${ }^{\mathrm{b}}$ \\ a Faculty of Technical Sciences, University of Warmia and Mazury in Olsztyn, Poland, \\ bartosz.moczulak@uwm.edu.pl, ORCID 0000-0002-4110-0273 \\ b Faculty of Technical Sciences, University of Warmia and Mazury in Olsztyn, Poland, \\ wojmek@uwm.edu.pl ORCID 0000-0001-6080-7357 \\ * Corresponding author: e-mail: bartosz.moczulak@uwm.edu.pl
}

\begin{tabular}{|c|c|}
\hline ARTICLE INFO & ABSTRACT \\
\hline $\begin{array}{l}\text { Article history: } \\
\text { Received: August } 2020 \\
\text { Received in the revised form: } \\
\text { September } 2020 \\
\text { Accepted: September } 2020\end{array}$ & \multirow{2}{*}{$\begin{array}{l}\text { The article presents the methodology of testing sliding } \\
\text { bearings with a flexible shell, focusing on the issue of } \\
\text { temperature increase during experiments for a specific } \\
\text { time interval of the START-STOP test cycle. Selected } \\
\text { material pairs, used in previous studies, were used in the } \\
\text { experiment. The stand used for tests in the start-stop cy- } \\
\text { cle was developed under the project POIG.01.03.01-00- } \\
027 \text { / 08-00 at the Faculty of Technical Sciences UWM } \\
\text { in Olsztyn. }\end{array}$} \\
\hline $\begin{array}{l}\text { Keywords: } \\
\text { foil bearings, } \\
\text { start-stop tests, } \\
\text { low-boiling medium }\end{array}$ & \\
\hline
\end{tabular}

\section{Introduction}

Tests of foil bearings in the working medium environment used in devices in which foil bearings were applied as elements of the bearings system, requires special procedures and test devices to be applied. Due to the nature of works carried out, and multi-thread approach to the use of foil bearings, the tests must be performed in a manner that enables analysis of various work conditions.

Bearings with an elastic bearing shell, such as foil bearings, operate as aerodynamic or hydrodynamic sliding bearings using viscosity of the surrounding medium for production of the load-bearing wedge (Daejong and Soongook, 2009; Dellacorte, 1997; Howard and San Andres, 2010).

The presented test stand enables performance of the START-STOP test in the presence of a medium which may be, for example, a working medium which supplies power microturbines simultaneously used for smearing bearings at the strictly defined working conditions. According to the authors, tests of foil bearings in the START-STOP cycle very well determine the life span of working elements of foil bearings, in particular of top and bump 
foils (Miąskowski et al., 2009a; Miąskowski et al., 2017; Michalak et al., 2014; Nalepa et al., 2013). The use of foil units in the mentioned bearings causes a higher reserve of stability since the shape of the oil gap in a bearing during its operation regularly adjusts to the present conditions. While lower dumping properties of a smear film are at the same time compensated with a bump foil dumping (Kiciński and Żywica, 2010; Kiciński et al., 2010; Miąskowski et al., 2009a; Miąskowski et al., 2009b). Tests of multi iteration cycles that perform sequences of run-up - work - rundown - break maintaining stable border conditions provide an answer to many questions that concern behaviour of working foils at various states of loading or various states of aggregation of the working factors of the performed START-STOP cycles including the suggested cooling system.

\section{Stand for foil bearings tests in the start-stop cycle with a cooling system of the test chamber}

A test chamber (Fig. 1) of the stand serves for the START-STOP cycle tests in the presence of a working medium. A sleeve that is a journal of the tested foil bearing is set on the conical ending of the shaft. A bearing foil unit is placed in the housing connected to an electromagnetic servomotor for induction of a transverse load of the investigated bearing. A detailed description of the test stand was presented in (Nalepa et al., 2013).

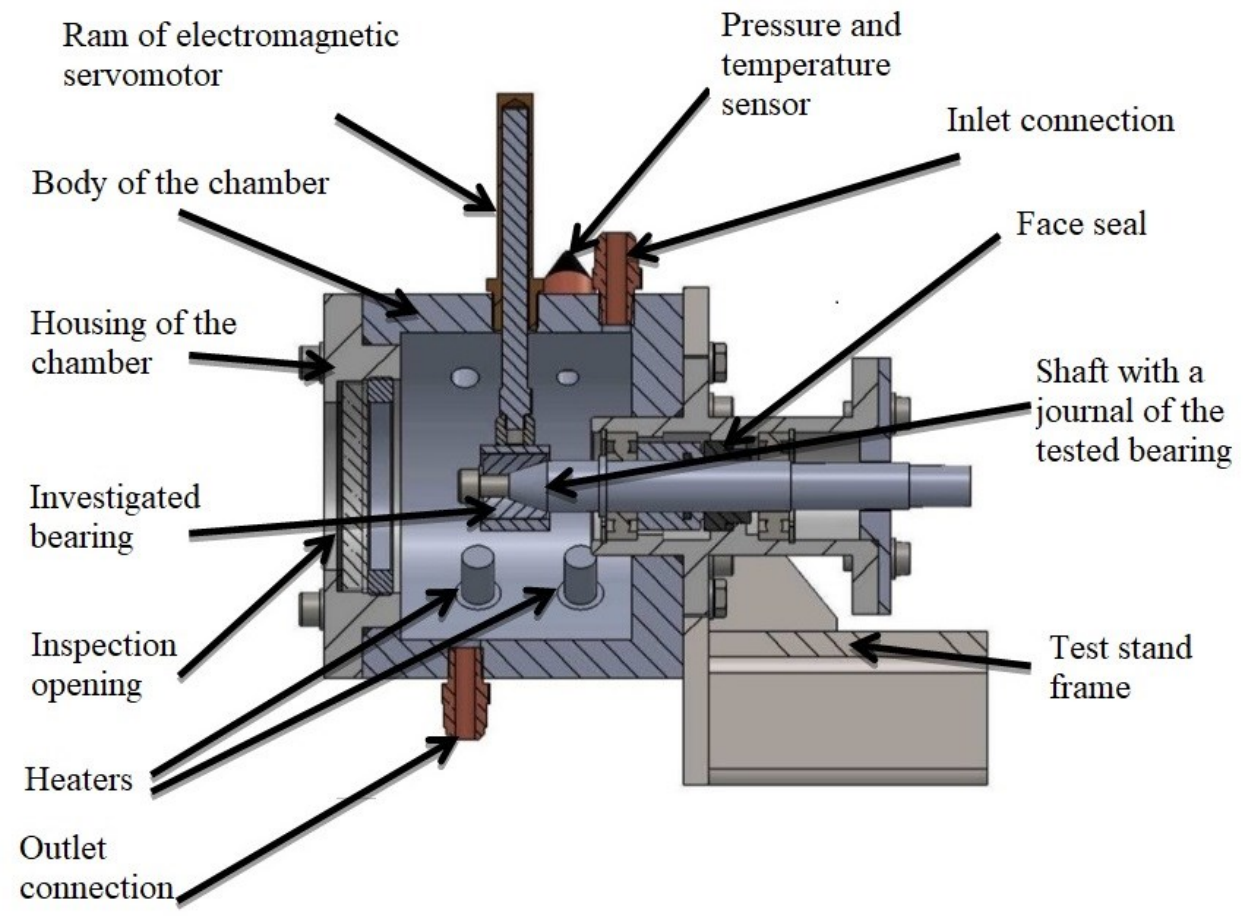

Figure 1. Stand for testing bearings in the start-stop cycle (Nalepa et al., 2013) 
Inside the chamber, a working medium is maintained in the set physical state (liquid, moist or dry steam). Heating elements that heat the working medium in the chamber combined with the supply system of the working medium enable obtaining the required conditions of temperature and pressure of the working medium. The working medium is supplied to the test chamber from the supply system with a connection pipe placed in the upper part of the chamber and removed in the bottom part (Fig.1).

To perform experiments consisting in approximation of real conditions of foil bearings and maintaining stable conditions in the test chamber, it was decided to firstly stabilize the temperature surrounding the tested foil unit. During the tests in the START-STOP cycle in the test chamber temperature of the medium increases under the influence of friction of the journal tip on the top foil and a ball bearing mounted in the housing (Fig. 2).
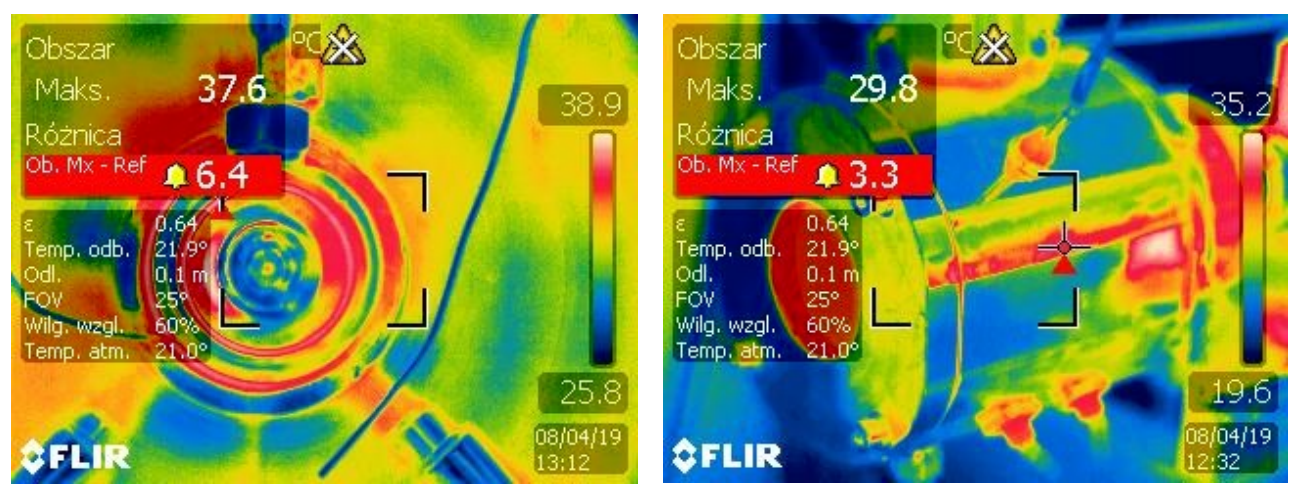

Figure 2. Image from the thermal imaging camera (Moczulak and Miaskowski, 2019)

When actions aiming at stabilization of temperature inside the test chamber during the test cycles were undertaken without using any specialistic systems of intake of the generated heat (e.g. Peltier links) it was decided to perform forced air convection around the test chamber. For this purpose, extraction of exhaust fumes was applied, directing a stream of the previously sucked air from the same room, where the test stand was located (Fig. 3). An exit hole of the elastic pipe was placed towards the test chamber in such a way that the air stream blowed around the chamber from the side of the low-boiling medium and the ball bearing block. The extractor of exhaust fumes worked with a constant performance during the entire test cycle.

In order to determine the temperature rise curve as a function of the number of test cycles, the initial measurements for 200 cycles were performed according to the previously established time interval (Moczulak and Miąskowski, 2019) for selected material pairs. The cycle of foil bearing operation on the test stand was carried out in the automatic mode for the sequence run-up - work - rundown - break (Tr=3(s), Tp $=3(\mathrm{~s}), T w=3(\mathrm{~s}), T n=10(\mathrm{~s}))$. The above-mentioned test will enable estimation of the dynamics of the temperature increase in the test chamber.

In the test chamber there are two thermocouples installed that enable measurement of temperature of the medium in the chamber and of the foil bearing housing (Fig.4). Firstly, it was decided to compare the registered readouts of both sensors. 

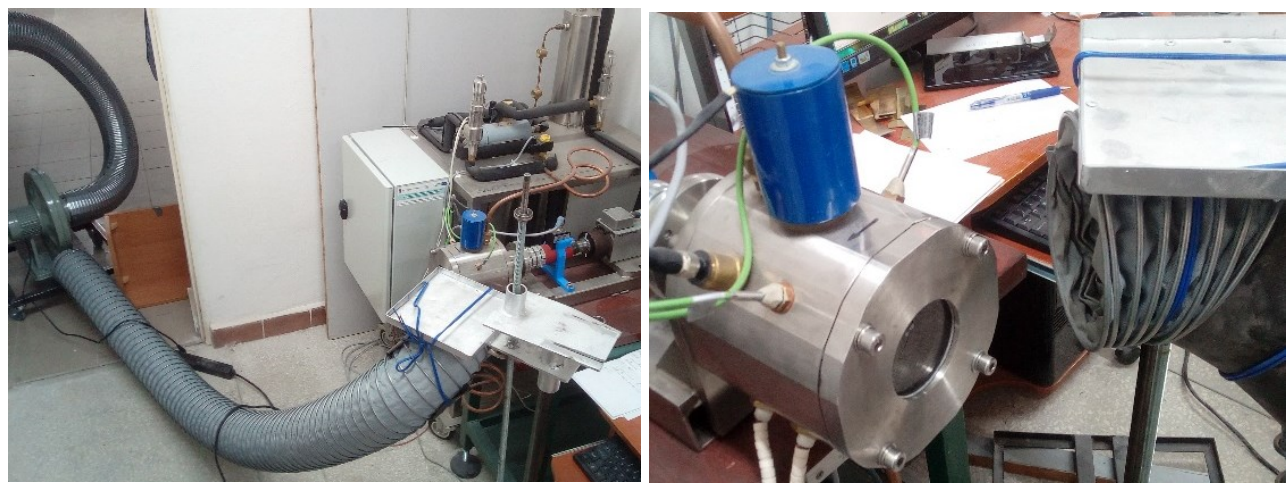

Figure 3. Proposed cooling system of the test chamber

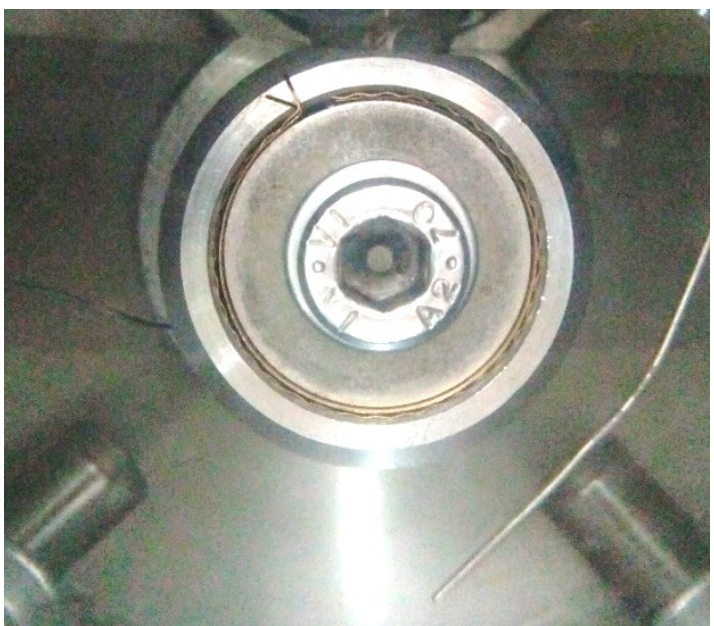

Figure 4. Installed thermocouples in the test chamber

When setting both curves (Fig. 5) one may observe that there are no clear differences in responses and derogations, and divergence of values of particular temperature sensors. The highest difference of responses with the value of $0.4^{\circ} \mathrm{C}$ occurred for the 74 th cycle.

The above-mentioned characteristics was performed for the material pair $2.0321 / \mathrm{CuAl} 7$ (top/bump) without cooling. Due to high compliance of responses, further plots will present responses from a thermocouple that measures temperature inside the test chamber (in the low-boiling medium).

To compare, results for these settings and material pairs were set with the results obtained during the experiment with a mounted cooling system of the test chamber. Results of the temperature increase in the test chamber at 200 cycles were presented in Figure 6. 
Methodology of testing...

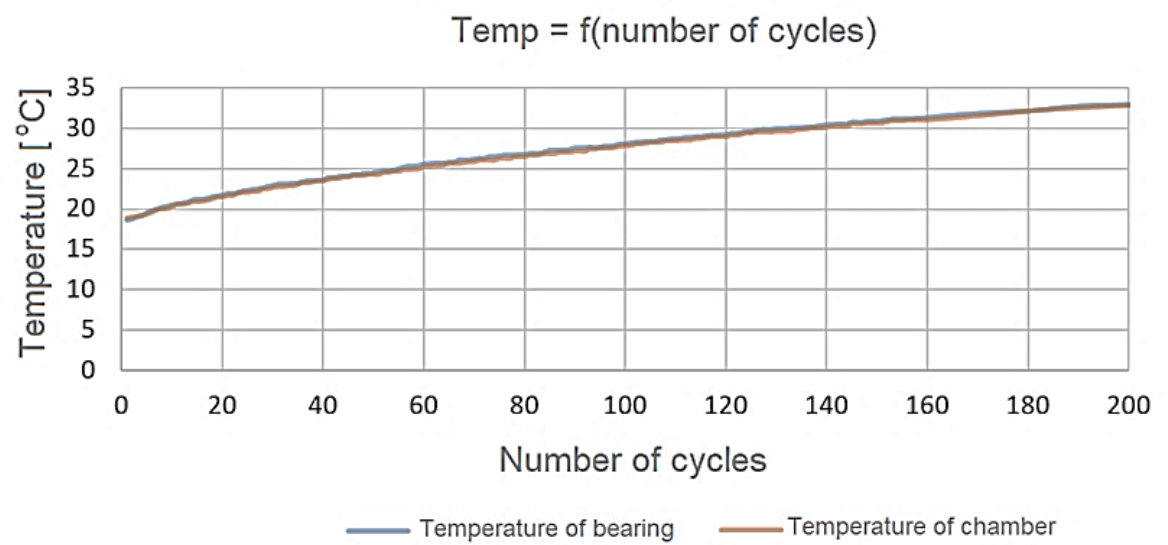

Figure 5.Curve of temperature increase measured on the foil bearing housing, and of the medium in the chamber for 200 cycles

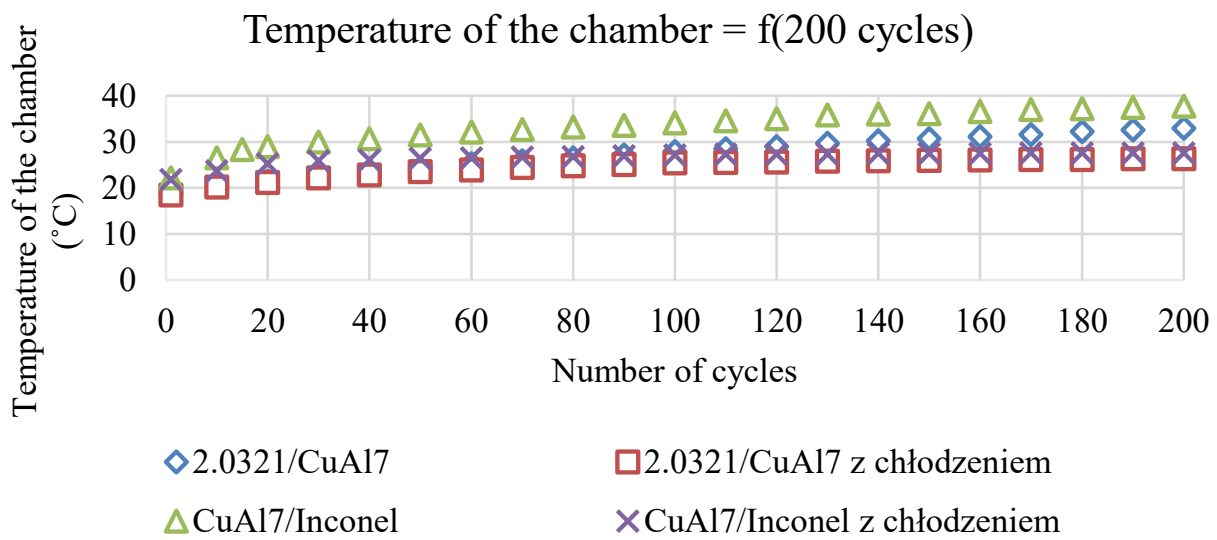

Figure 6. Low-boiling medium temperature rise curve for 200 cycles, considering cooling of the test chamber and no cooling

When analysing the curve of the temperature rise of the low-boiling medium for two material pairs and one setting of time intervals, one may conclude that the used cooling system fulfils its task, stabilizing the temperature in the test chamber. The used material pairs had various thickness of structural elements of the foil bearing which had a direct impact on the value of resistance of motion and thus friction and increase of the emitted heat. Therefore, for the material pair $\mathrm{CuA17/Inconel} \mathrm{(top/bump)} \mathrm{one} \mathrm{may} \mathrm{observe} \mathrm{a} \mathrm{clearer} \mathrm{difference} \mathrm{of} \mathrm{the}$ temperature rise.

A trial of 200 cycles for settings of the time interval run-up - work - rundown - break $(\operatorname{Tr}=3(\mathrm{~s}), \mathrm{T} p=10(\mathrm{~s}), T w=3(\mathrm{~s}), T n=10(\mathrm{~s}))$ is not meaningful from the point of view of 
Bartosz Moczulak, Wojciech Miąskowski

multi iteration test cycle but is a perfect signal and indicator of advantages from using the suggested cooling system. START-STOP cycle in the relatively stable conditions in the test chamber is one of many directions of targeted test trials. For the above-mentioned iterations, mass losses of specific bearing foils were reported (Table 1).

Table 1 .

Mass and mass loss of selected material pairs after 200 cycles

\begin{tabular}{lccc}
\hline \multirow{2}{*}{ Specification } & & top/bump & top/bump \\
& Foil type & $\mathbf{2 . 0 3 2 1 / \text { CuAl7 }}$ & CuAL7/Inconel \\
\cline { 2 - 4 } & & Mass $(\mathrm{g})$ & Mass $(\mathrm{g})$ \\
\hline Foil mass before tests & top & 1.58070 & 1.55029 \\
Foil mass after 200 cycles & bump & 1.62310 & 1.72295 \\
(without cooling) & top & 1.58067 & 1.54941 \\
Foil mass after 200 cycles & bump & 1.62293 & 1.72284 \\
(with cooling) & top & 1.58056 & 1.54910 \\
& bump & 1.62255 & 1.72278 \\
\hline Mass loss "without & & top/bump & top/bump \\
cooling" (g) & top & $\mathbf{2 . 0 3 2 1 / C u A l 7}$ & CuAL7/Inconel \\
Mass loss "with & bump & 0.00003 & 0.00088 \\
cooling" (g) & top & 0.00018 & 0.00011 \\
\hline
\end{tabular}

As a result of various configurations of material pairs, mass consumption of specific bearing foils is also not clear. In table 1 we may notice higher mass consumption of top foil for the material pair CuAl7/Inconel (top/bump), while for the material pair $2.0321 / \mathrm{CuAl} 7$ (top/bump), top foil has a higher mass consumption. A higher mass loss of the couple $\mathrm{CuAl} /$ Inconel may be reported for the studies without chamber cooling while in the foil unit $2.0321 / \mathrm{CuAl} 7$ for the studies performed with chamber cooling.

After 200 START-STOP cycles, mass consumption of foil is within 0.0001-0.0008 g.

A similar methodology of research was applied for the trial of 1000 cycles for which also the sensor temperature was registered in the test chamber and mass consumption, but measurements were made only with the test chamber cooling. The aim of the trial of 1000 STARTSTOP cycles was determination of the correctness of using the cooling system and stabilization of temperature in the entire research cycle for various material pairs of particular bearing foils.

During the first trial of 1000 cycles the attention was also paid to the responses of the thermocouple placed in the low-boiling medium and touching the housing of the bearing. Results of this measurement were presented in figure 7.

In this case, as well, a high compliance of responses of both temperature sensors was reported. Thus, in further analyses a decision was made to register the temperature of the agent in the test chamber.

A series of multi-repeated test in the START-STOP cycle for 1000 cycles in the presence of a low-boiling medium was performed for the selected material pairs. The temperature rise curve at the simultaneous cooling of the test chamber was presented in figure 8 . 
Methodology of testing...

Temp $=f$ (number of cycles)

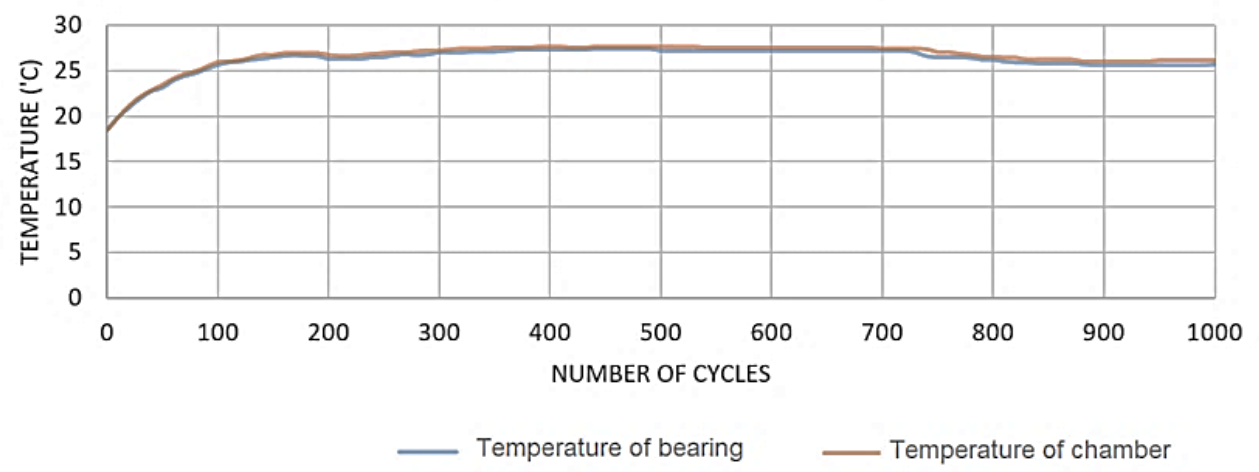

Figure 7. Curve of temperature increase measured on the foil bearing housing and of the medium in the chamber for 1000 cycles

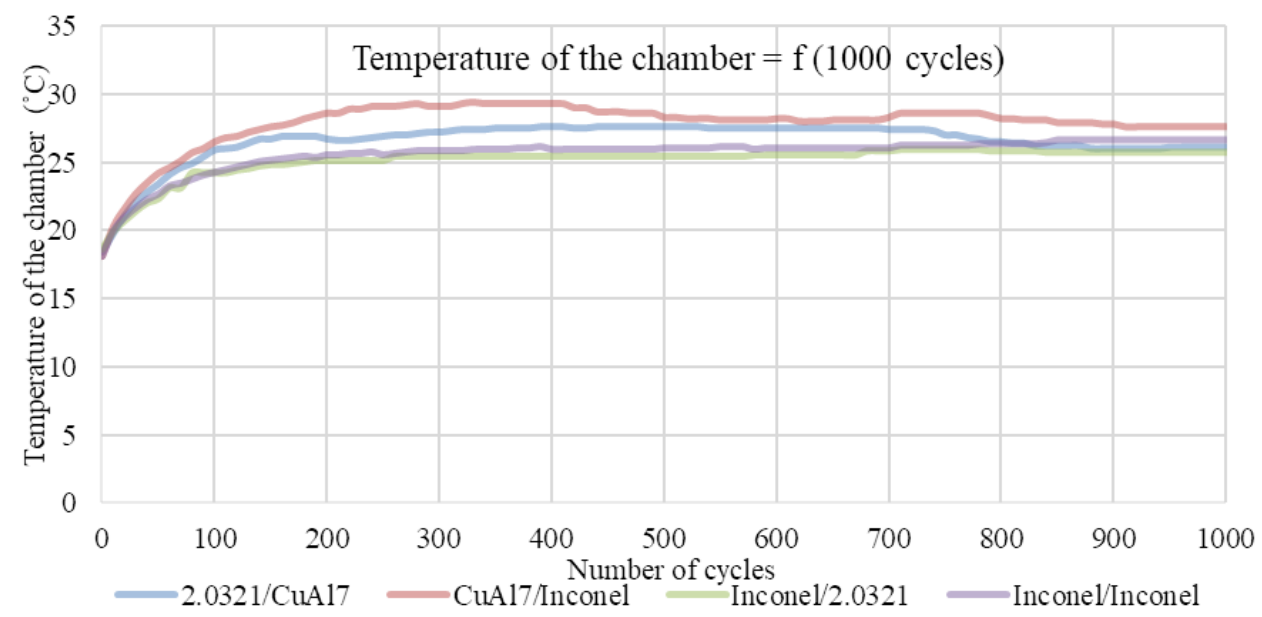

Figure 8. Low-boiling medium temperature increase curve for 1000 cycles considering selected material pairs with simultaneous cooling of the test chamber

Plot 4 clearly shows temperature stabilization in the test chamber for the series of 1000 iterations for each used material pair. It proves the maintenance of close, comparable, and quasi-stable conditions in the test chamber during START-STOP cycles and thus the efficiency of the used cooling system. Mass consumption of particular foils was set in table 2 .

As a result of various configurations of material pairs, mass consumption of specific bearing foil is also not clear. An increased rise of mass consumption in these foil units, where Inconel is used, is visible. Due to the nature of cooperation and type of friction with, the top foil has a higher consumption. 
Bartosz Moczulak, Wojciech Miąskowski

Table 2.

Mass and mass loss of selected material pairs after 1000 cycles

\begin{tabular}{lccccc}
\hline Specification & type & $\begin{array}{c}\text { top/bump } \\
\mathbf{2 . 0 3 2 1 / C u A l 7} \\
\text { Mass }(\mathrm{g})\end{array}$ & $\begin{array}{c}\text { top/bump } \\
\text { CuAL7/Inconel } \\
\text { Mass (g) }\end{array}$ & $\begin{array}{c}\text { top/bump } \\
\text { Inconel/2.0321 } \\
\text { Mass (g) }\end{array}$ & $\begin{array}{c}\text { top/bump } \\
\text { Inconel/Inconel } \\
\text { Mass (g) }\end{array}$ \\
\hline Foil mass before & top & 1.58058 & 1.54907 & 1.70038 & 1.69239 \\
tests & bump & 1.62285 & 1.72287 & 1.64011 & 1.64944 \\
Foil mass after tests & top & 1.58017 & 1.54738 & 1.69994 & 1.69145 \\
(with cooling) & bump & 1.62269 & 1.72281 & 1.64002 & 1.64929 \\
\hline \multicolumn{2}{l}{} & $\mathbf{2 . 0 3 2 1 / C u A l 7}$ & CuAL7/Inconel & Inconel/2.0321 & Inconel/Inconel \\
\hline Mass loss with cool- & top & 0.00041 & 0.00169 & 0.00044 & 0.00094 \\
ing (g) & bump & 0.00016 & 0.00005 & 0.00009 & 0.00015 \\
\hline
\end{tabular}
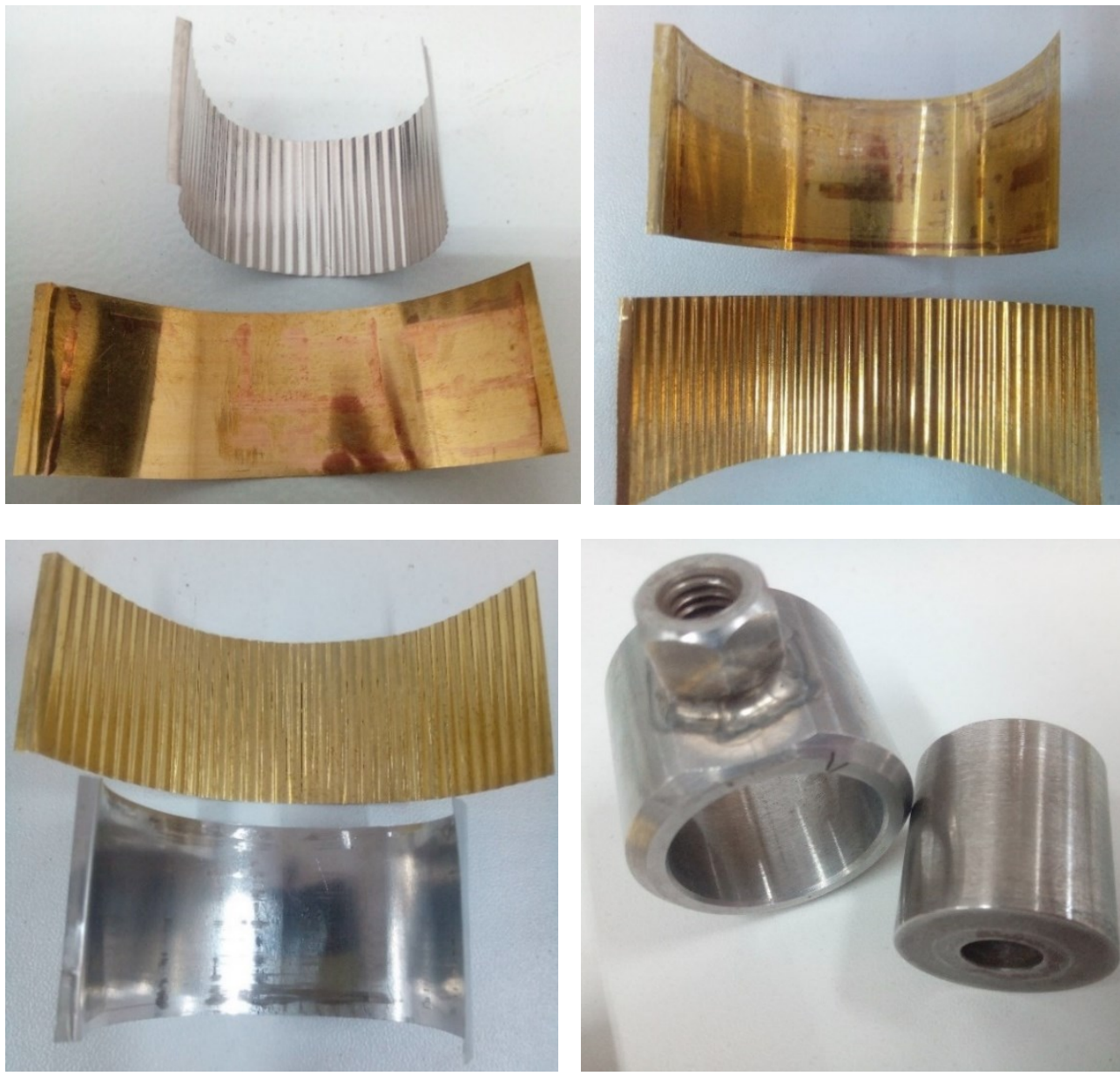

Figure 9. View of the degree of wear of the bearing foil along with the wear of the journal surface and the bearing housing 
Specific foils after 1000 cycles START-STOP did not have an excessive consumption of external surfaces (Fig. 9). The organoleptic analysis that was carried out, did not prove any serious losses also on the internal surface of the bearing housing and the external surface of the shaft journal. Measurement of the shaft journal after several thousand cycles did not prove any losses. Extension of that assessment of wear of the foil units is possible thanks to microscopes and profilographs which serve for measurement of roughness, corrugated nature, and shape e.g. with an optical method. A three-dimensional mapping of cooperating surface is also possible (Komar, 2015).

\section{Conclusion}

After performance of the series of START-STOP cycle tests for various material pairs in foil bearings in a low-boiling agent, it may be concluded that the suggested cooling system fulfilled its role maintaining the temperature in the test chamber at performing trials of 1000 cycles within $25-30^{\circ} \mathrm{C}$. Particular temperature sensors did not show clear differences of responses and derogations and divergences of the temperature values inside the test chamber. The presented methodology of research ensures maintenance of stable conditions of operation of the bearing during performance of multi-repeated tests in the start-stop cycle for various material pairs and their various configurations.

Mass consumption of particular foils for various material configurations and their thickness is not clear to determine. Besides, after performance of the trial of 1000 START-STOP cycles the maximum consumption of the top foil is $0.00169 \mathrm{~g}$ and the minimum foil consumption is $0.00041 \mathrm{~g}$. Bump foil had a maximum consumption of $0.00016 \mathrm{~g}$. Measurement of the mass consumption serves not only for determination of the material losses but also indicates the need to perform a higher number of START-STOP cycles as a test that shows the life span of the foil units in foil bearings.

The tests presented in the articles constitute one of many test paths which will be performed as a part of works related to the experimental analysis of foil bearings in the STARTSTOP cycle.

\section{References}

Daejong, K., Soongook, P. (2009). Hydrostatic air foil bearings: Analytical and experimental investigation. Tribology International, 42, 413-425.

Dellacorte, C. (1997). A new foil air bearing test rig for use to $700^{\circ} \mathrm{C}$ and $70,000 \mathrm{rpm}$. NASA TM107405 .

Howard, S.A., San Andres, L. (2010). A new analysis tool assessment for rotordynamic modeling of gas foil bearings. ASME Turbo Expo 2010: Power for Land, Sea and Air GT2010, Glasgow, UK (GT2010-22508).

Kiciński, J., Żywica, G., Miąskowski, W. (2010). The Dynamic Properties of the Micro-Rotor Supported on Fluid-Film Bearings. IFToMM International Conference on Rotor Dynamics. Seoul (South Korea), 681-685.

Kiciński, J., Żywica, G. (2010). The numerical analysis of the steam microturbine rotor supported on foil bearing. Advances in Vibration Engineering, 11, 113-119.

Komar, W. (2015). Analiza zużycia cienkiej folii metalowej. Mechanik, 7, 417-424

Miąskowski, W., Nalepa, K., Żywica, G. (2009a). Foil micro-bearing tests. Technical Sciences, 12, 249-258. 
Bartosz Moczulak, Wojciech Miąskowski

Miąskowski, W., Pietkiewicz, P., Żywica, G. (2009b). Modelling foil bearing. Technical Sciences, 12 , 241-248.

Miąskowski, W., Moczulak, B., Nalepa, K., Pietkiewicz, P., Komar, W. (2017). START-STOP analysis of high-speed bearings with a flexible bushing, International Multidisciplinary Scientific GeoConference Surveying Geology and Mining Ecology Management, SGEM, PAPER, 628-632. doi:10.5593/sgem2017H/63/S24.009

Michalak, M., Michalczewski, R., Piekoszewski, W., Szczerek, M., Wulczyński, J. (2014). Urządzenie do badania odporności na zużycie materiałów przeznaczonych na elementy łożysk foliowych. Tribologia, 3, 131-142.

Moczulak, B., Miąskowski, W. (2019). Methods of research of foil bearings in START-STOP cycle in the presence of working medium. Agricultural Engineering, 23, 41-51.

Nalepa, K., Miąskowski, W., Pietkiewicz, P., Miazio, Ł. (2013). Stanowisko do badania łożysk foliowych w cyklu Start-Stop w obecności czynnika niskowrzącego. Mechanik, 7, 519-524.

\section{METODYKA BADAŃ LOŻYSK FOLIOWYCH W CYKLU START-STOP W OBECNOŚCI CZYNNIKA ROBOCZEGO - STABILIZACJA TEMPERATURY W KOMORZE BADAWCZEJ}

Streszczenie. W artykule przedstawiono metodykę badań łożysk ślizgowych z elastyczną panwią, skupiając się na zagadnieniu wzrostu temperatury podczas przeprowadzania doświadczeń dla określonego przedziału czasowego cyklu badań typu START-STOP. W doświadczeniu wykorzystano wybrane pary materiałowe, wykorzystywane we wcześniejszych badaniach. Stanowisko wykorzystywane do badań w cyklu start-stop zostało opracowane w ramach projektu POIG.01.03.01-00-027/08-00 na Wydziale Nauk Technicznych UWM w Olsztynie.

Słowa kluczowe: łożyska foliowe, badania start-stop, czynnik niskowrzący 